\title{
HOTS study primary teacher education UNNES students based on self-regulated learning
}

\author{
Nursiwi Nugraheni *, St. Budi Waluya, Walid Walid \\ Universitas Negeri Semarang. Gunungpati, Sekaran, Semarang, 50229, Indonesia \\ * Corresponding Author. E-mail: nursiwi_n@students.unnes.ac.id
}

Received: 7 December 2020; Revised: 18 December 2020; Accepted: 31 December 2020

\begin{abstract}
This research aims to study students' High-Order Thinking Skills (HOTS) in the Primary Teacher Education Department of Universitas Negeri Semarang (UNNES) viewed from their Self-Regulated Learning (SRL). The research method in this research is a mixed method of a sequential explanatory model. This research was conducted in the Department of Primary Teacher Education at UNNES for class 2020 in the Basic Mathematical Concept course. Data collection techniques using questionnaires, documentation, interviews. Analysis of quantitative data in the form of validity and reliability of the instrument was followed by descriptive analysis. Qualitative data analysis was performed by triangulation and descriptive statistical analysis. A study of quantitative data found two categories of the level of SRL, namely medium and high levels. The results of the analysis of student answers were obtained: (1) Students with moderate SRL category interpret the questions into Mathematical language, and the way they identified the problem is less communicative, while the students with high SRL category interpret the questions into Mathematical language communicatively; (2) Based on students' ability to evaluate, students with moderate SRL category have not been fluent yet, while the students with high SRL category have been fluent in evaluating, and (3) Based on their creativity, students with moderate SRL still need more practices, while students with high SRL category have been fluent. The conclusion of this study is the ability to interpret problems and the habit of examining problem-solving carried out into the differences between the two categories.
\end{abstract}

Keywords: HOTS, self-regulated learning.

How to Cite: Nugraheni, N., Waluya, S., \& Walid, W. (2021). HOTS study primary teacher education UNNES students based on self-regulated learning. Jurnal Prima Edukasia, 9(1), 127134. doi:https://doi.org/10.21831/jpe.v9i1.36359

\section{Introduction}

Since the students are over the age of 18 , they should have distinguished information from various sources of knowledge, including the internet, whether the information is credible or not. At this age, students have been independent in thinking, such as building independent learning. Being away from parents makes them able to take self-responsibility. It does not only about the basic needs, but also the needs to study more knowledge since they have been at the university level. At their age, parents and lecturers should no longer remind them to take responsibility to study independently. Every student should consciously apply Self-Regulated learning for their learning success. Every student should have a vision and mission from the first semester. In other words, they have to arrange plans for their future from the beginning of college. Learn to be independent, conduct independent learning, and finish the assignments independently are lecturers' hopes for their students. However, most of the students still have to be guided since they wait for the materials, the assignments, and the detailed instructions for doing their assignments from the lecturers without initially looking for the information. Even, they still rely on friends or parents in finishing their assignments. Also, if the lecturers forget to evaluate their assignments, they tend to be happy, without any desire to know how much competence they have mastered. During the COVID-19 pandemic, online learning is conducted at various levels of education, including the Primary Teacher Education Departments of UNNES. In the implementation of E-learning, Self-Regulated Learning is required.

High-Order Thinking Skills has become the topic discussed by educational researchers currently since many studies have highlighted this. Besides Mathematical problem-solving skills and Mathematical communication skills, High-Order Thinking Skills have also been popular among educators. The 
Jurnal Prima Edukasia, 9 (1), 2021 - 128

Nursiwi Nugraheni, St. Budi Waluya, Walid Walid

upper levels of Bloom's taxonomy are understood to be Higher-Order Thinking (Sole \& Anggraeni, 2020). Hence, it is necessary to improve HOTS to compete in life (Agung Ramadan et al., 2020). However, the reality is the development of Mathematical High-Order Thinking Skills is not optimal currently (Payadnya \& Atmaja, 2020). Based on the National Exam results in 2018, Indonesian students' HOTS, such as understanding, analyzing, and evaluating, are still weak (Setiawati et al., 2018). Therefore, the purpose of this research is to examine students' HOTS of the Primary Teacher Education Department of UNNES, based on their Self-Regulated Learning.

\section{Method}

This research was conducted at the Primary Teacher Education Department of UNNES, for students in the first year (2020), in Basic Mathematical Concept class. The researchers implemented mixed methods of a sequential explanatory model. The research was conducted with a quantitative research sequence and then continued with qualitative research - data collection techniques using questionnaires, documentation, interviews. Analysis of quantitative data in the form of validity and reliability of the instrument was followed by descriptive analysis. Qualitative data analysis was performed by triangulation and descriptive statistical analysis. Quantitative research is used to identify the level of student learning independence as the basis for selecting subjects for qualitative research. The SRL questionnaire consisted of 36 items that were tested on 137 students. Since three invalid questions were discarded, so the number of the questions was only 33 questions. The reliability of 33 questions was tested, and the results indicated that the instrument has been reliable. The activity was designed by distributing a questionnaire about SRL to 119 students. Based on the results of the questionnaire, students with low SRL were not found. It is in line with previous researchers' statement that students should have been independent, based on their age. After that, three students with high SRL and three students with moderate SRL were selected. A test was applied to test students' HOTS. Then, the work results as a document were analyzed and triangulated with the interview about their work results.

\section{Result and Discussion}

One of the cognitive operations required in the short-term memory thinking process is HOTS (Citrasukmawati et al., 2020) since skills to solve the problem, skills to think creatively, skills to think critically, skills to make argumentative, and skills to make a decision are covered in HOTS (Payadnya \& Atmaja, 2020). Students' adaptability in 21st-century competitions is related to their HOTS abilities (Ichsan et al., 2020). Previous national and international studies show Indonesian students' HOTS (Edwar, 2020). Hence, Higher-Order Thinking Skills are measured by using several questions related to HOTS. Students do not only remember, repeat, or recite in HOTS but also involving higher-order thinking processes. Hence, students still need encouragement and guidance (Shidiq et al., 2015). HOTS questions in the assessment context aim to measure the ability for (1) transferring one concept to another, (2) processing and applying information, (3) looking for the links from various information, (4) using the information to solve problems, and (5) examining ideas and information critically (Setiawati et al., 2018). Remember (C1), understand (C2), apply (C3), analyze (C4), evaluate (C5), and create (C6) are the stages of Bloom's Taxonomy. People who can apply are not necessarily able to solve problems (problem-solving skills) (Setiawati et al., 2018). Meanwhile, Higher-Order Thinking Skills consist of skills to analyze, evaluate, and create. Higher-order thinking skills are logical, critical, and creative thinking skills, such as independence in solving the problem (Setiawati et al., 2018). Logical thinking is the ability to think critically. Critical thinking can be accepted by common sense and meets scientific thinking principles. Critical thinking involves using knowledge and experience to analyze new things, such as comparing or identifying strengths and weaknesses in making decisions. Meanwhile, creative thinking is the ability to develop new or different ideas that aim to make various innovations in solving real problems. Thus, Higher-Order Thinking Skills consist of skills to solve problems, think critically, think creatively, and abilities to make a decision (Setiawati et al., 2018). The literature review reveals that HOTS is one of the main goals in education and has become one of five variables that can improve students' achievement (Pratama \& Retnawati, 2018). The assessment instrument is developed based on HOTS indicators, including the ability to analyze (C4), evaluate (C5), and create (C6) (Kusuma et al., 2017). HOTS assessments consist of questions or tasks that review these following characteristics: to assess students abilities to analyze, evaluate, and create based on contextual issues, that are not routine 
(not familiar) (Widana, 2017). HOTS assessment is in the form of questions that generally measure the ability to analyze, evaluate, and create (Fanani, 2018). In other words, High-Order Thinking Skills is aimed to make students capable of solving questions, thinking critically, evaluating, and creating.

In HOTS questions, the analyzing category (C4) is as follows: Mr Ilman has a rose garden with a rectangular surface. Mr Ilman's garden is adjacent to Mr Arie's garden on one side, which is $30 \mathrm{~m}$. Mr Arie's land surface is also rectangular. The circumference of Mr Arie's garden is three times larger than Mr Ilman's garden, while Mr Illman's garden's rim is $120 \mathrm{~m}$. Meanwhile, Mr Arie wants to plant mango trees to surround his garden with a distance of 1 meter for each tree from the other trees. The mango tree is used as a barrier with other gardens. However, the side bordering Mr Ilman's garden has already been planted with teak trees, so mango trees do not need to be planted. How many mango trees should Mr Arie prepare?

The first student with moderate Self-Regulated Learning, who is in the lowest position, is UA. He cannot solve the problem yet, and the answer sheet is blank. The second student with moderate SelfRegulated Learning, who is in the middle position, is FMR. FMR has interpreted the story in the questions into mathematical language even though the problem identification has not been written completely. And problem-solving is incorrect. In other words, FMR is incapable of solving the problem. The third student with moderate Self-Regulated Learning, who is above or close to the High SelfRegulated Learning category, is FAS. FAS interprets the problems in the story into mathematical language and identifies problems more completely than FMR. Although FAS' answer is incorrect, she has tried to describe the problem, even though he is not thorough. Based on the results of the interviews, the three students with Self-Regulated Learning are not thorough in reading and interpreting math problems. If the ability to interpret mathematical problems is less influential in the problem-solving process, it will make difficulties in linking materials.

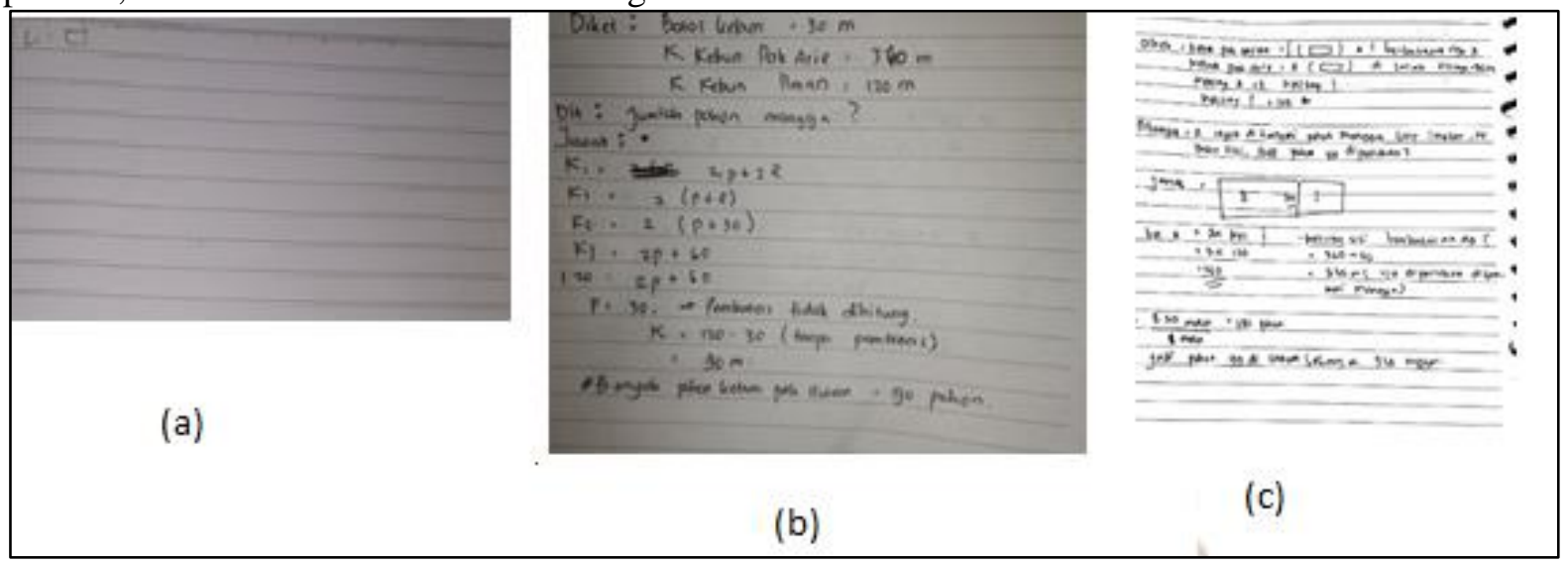

Figure 1. (a) The first answer of UA, (b) the first answer of FMR, (c) the first answer of FAS

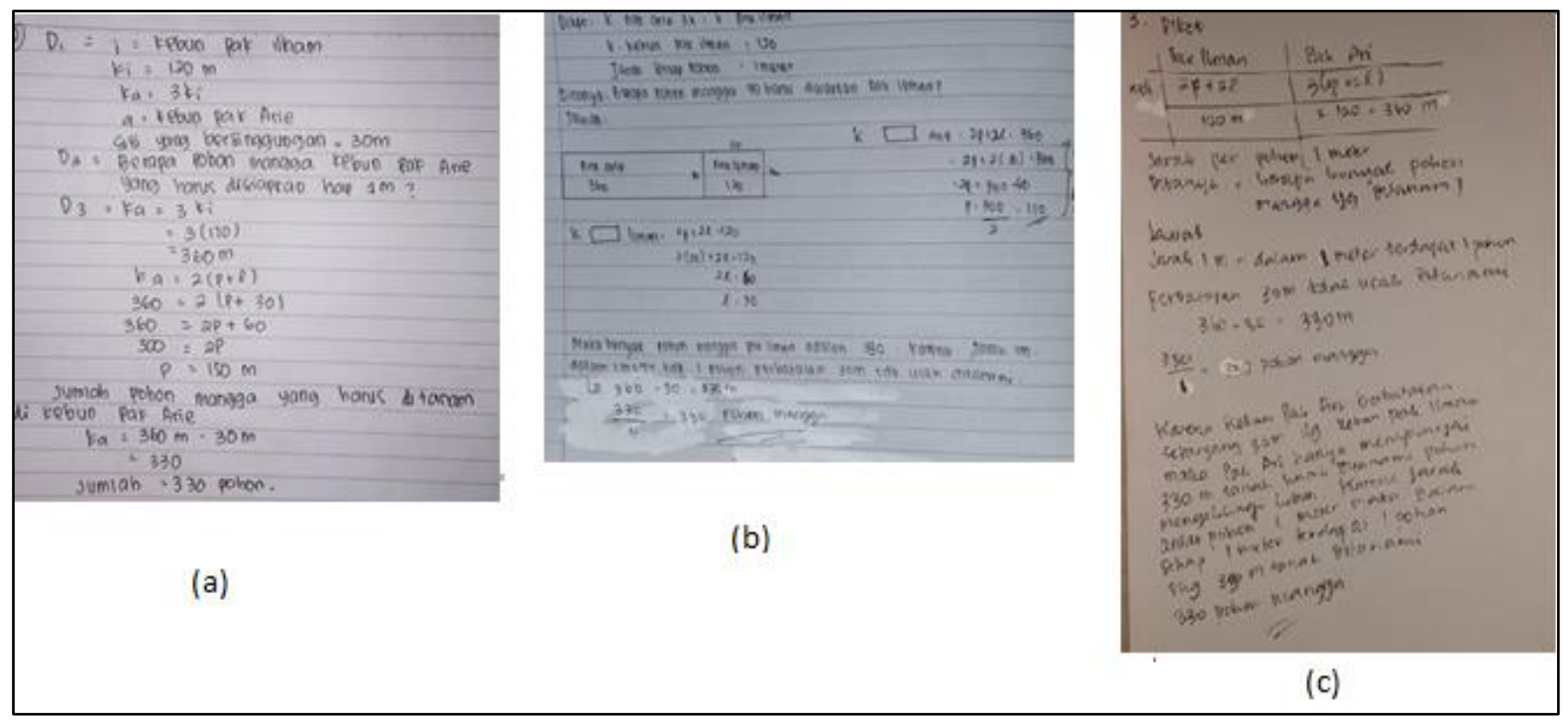

Figure 2. (a) The first answer of LS, (b) the first answer of ARAD, (c) the first answer of MD 
The first student with the lowest position in the high Self-Regulated Learning category is LS. Meanwhile, LS's work results are similar to FAS's. The second student with moderate Self-Regulated Learning category is ARAD. ARAD's work is also identical to FAS's, except for its length. The third student with a high Self-Regulated learning category is MD. MD's answer is also similar to FAS, LS, and ARAD. Even though some of them have drawn, no one has been able to identify the concept of perimeter and distance between plants that are slightly different. Based on the idea of fencing the garden with mango trees which are 1 meter away, there is 1 point in the corner that is counted twice, as confirmed during the interview. One student, namely ARAD, was able to elaborate on his answer after being asked repeatedly.

Based on HOTS questions, the evaluating category (C5) is as follows: Adi went out with his friends. Since it was already noon, they went to the restaurant for lunch. Adi ordered a package of rice, two kinds of vegetables, and three side dishes. He paid with fifty thousand rupiah banknote, and the changes were 6 thousand rupiah banknote and one thousand rupiah banknote. Hasan ordered two portions of rice, one kind of vegetables, and four side dishes. He paid with one hundred thousand rupiah banknote, and the change was twenty thousand rupiah banknote, 3 ten thousand rupiah banknote, 3 two thousand rupiah banknote, and 2 five hundred rupiah coins. Nana ordered one portion of rice, one kind of vegetable, and two side dishes. She paid with twenty thousand rupiah banknote and ten thousand rupiah banknote, and she got two thousand rupiah banknote and four coins of five hundred rupiahs as the changes. Fatma ordered a portion of rice, two kinds of vegetables, and one side dish and paid with 50 thousand rupiah banknote. She got changes of twenty thousand rupiah banknote and 4 two thousand rupiah banknotes. Did the cashier count correctly? Give the reason for your answer!

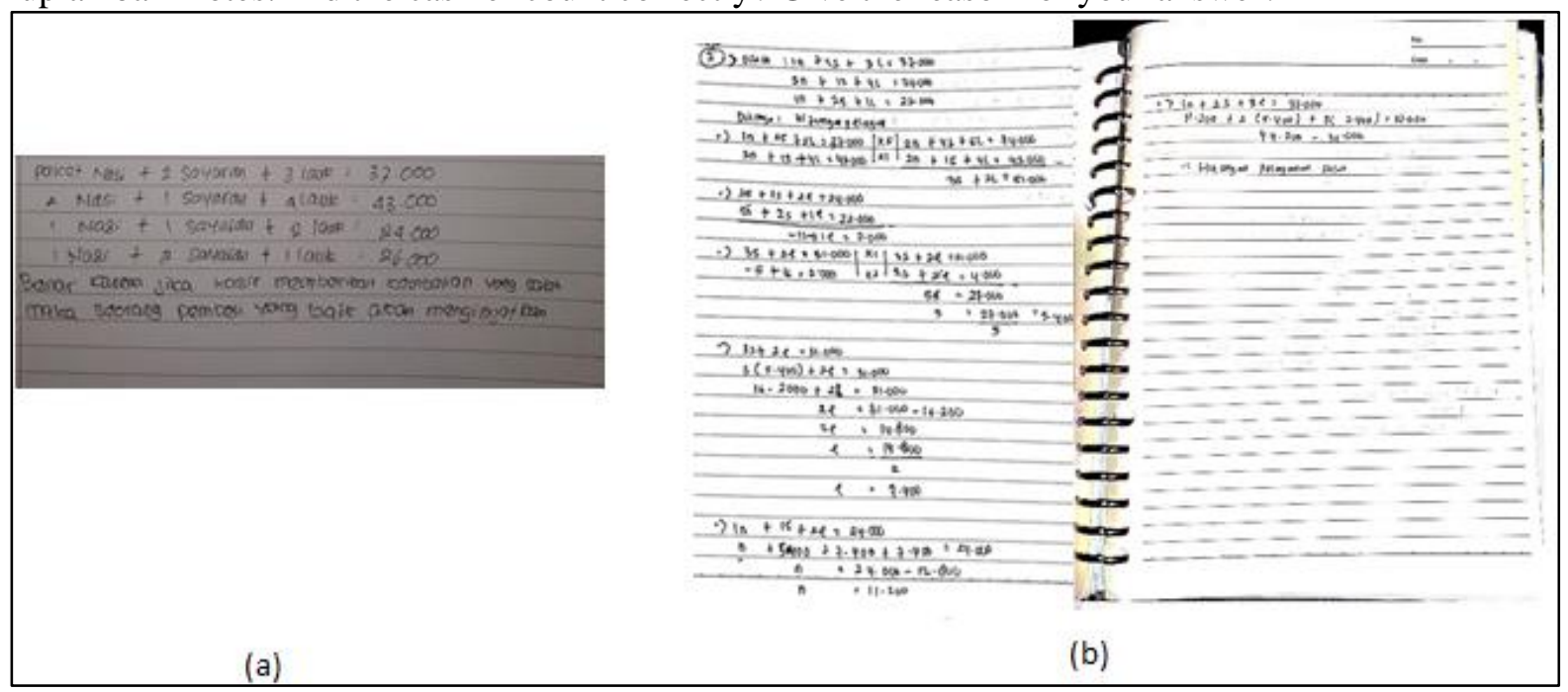

Figure 3. (a) The second answer of UA, (b) the second answer of FMR

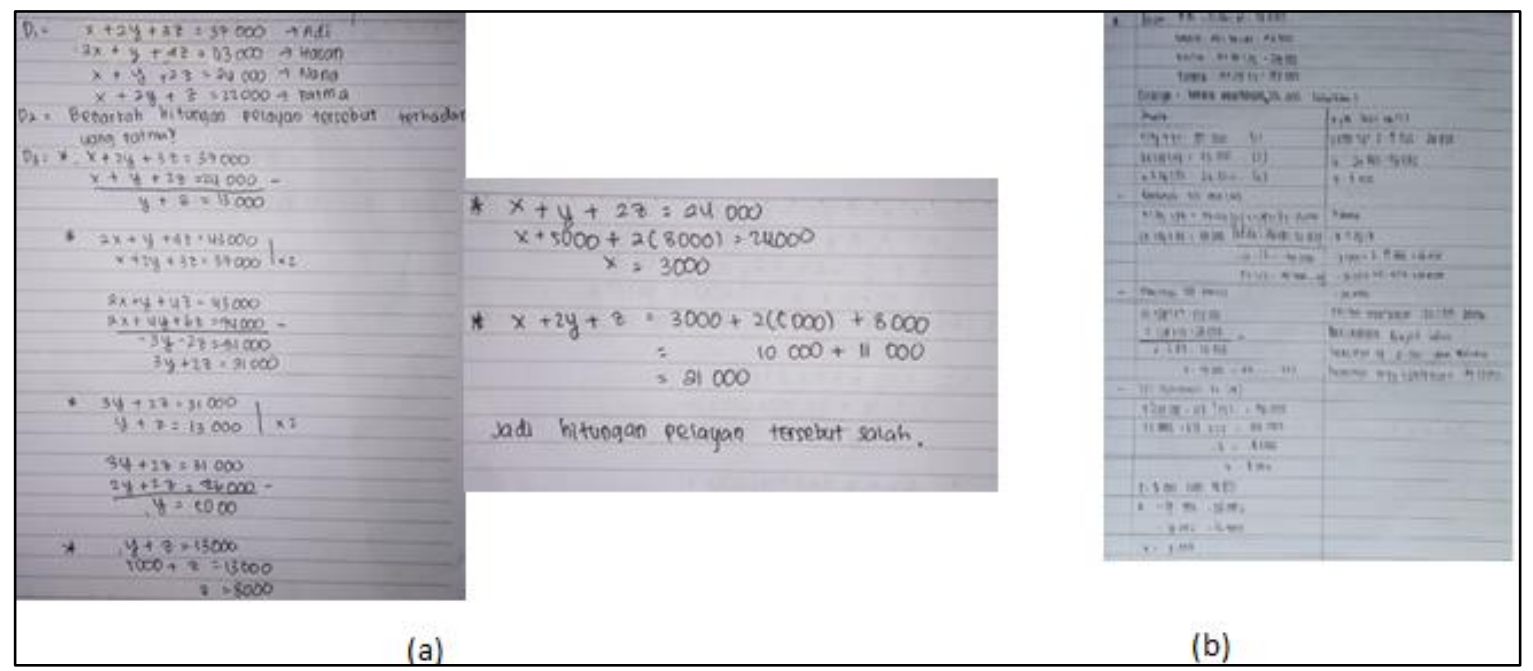

Figure 4. (a) The second answer of FAS, (b) the second answer of LS 
Jurnal Prima Edukasia, 9 (1), 2021 - 131

Nursiwi Nugraheni, St. Budi Waluya, Walid Walid

UA's only answers and writes what has been known from the question; FMR did not write down any answers, while FAS has interpreted the questions in Mathematical language. However, the way FAS elaborate on the problem identification is less communicative. Thus, FAS has been able to write down decisions even though it is less communicative. Also, even though the decision is correct, the reason for the decision is still incorrect. After conducting interviews, UA, FMR, and FAS have difficulties in interpreting math problems. Thus, three of them also have difficulties in solving math problems, while the ability to interpret HOTS questions is important in solving math problems.

LS has been able to decide like FAS even though their calculations o are different, and LS' answer is correct. Meanwhile, ARAD's and MD's answers are similar to LS's. The three of them were able to decide since all of them can interpret math problems. Hence, the steps to solve the problem are systematic since the right decisions make the right reasons. They are accustomed to re-checking the steps of solving the problem to prevent any possibility of a small miscalculation. The habit of reexamining answers is not possessed by students with a moderate level of SRL.

In HOTS questions, the creative category (C6) is as follows: The price of 5 books, two pencils, and three erasers is paid with 3 ten thousand rupiah banknotes and 2 five hundred coins. The price of 4 books, three pencils, and two erasers is paid for 2 ten thousand rupiahs and 3 two thousand rupiah banknotes and 1 five hundred rupiah coin. The price of 2 books, two pencils, and four erasers was paid with twenty thousand rupiah banknote and get change for 1 two thousand note and 2 of five hundred rupiah coins. Meisya has IDR 27,000.00. She needs books, pencils, and an eraser for compulsory school purposes. Give five possibilities for how many books, pencils, and erasers she can buy! Explain!

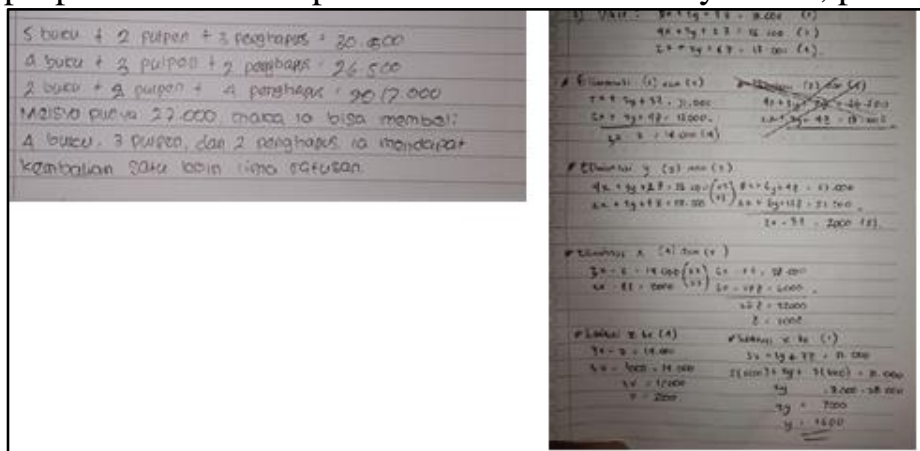

(a)

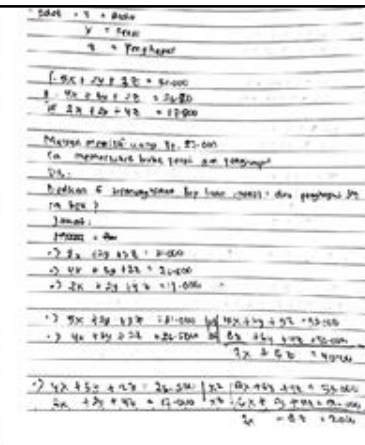

(b)

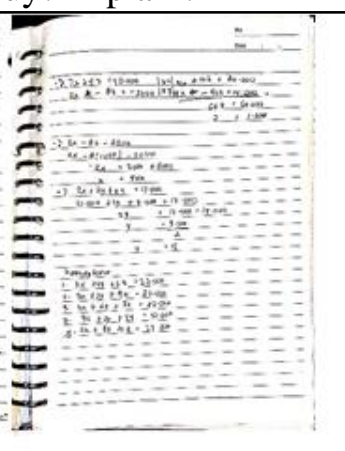

(c)

Figure 5. (a) The third answer of UA, (b) the third answer of FMR, (c) the third answer of FAS

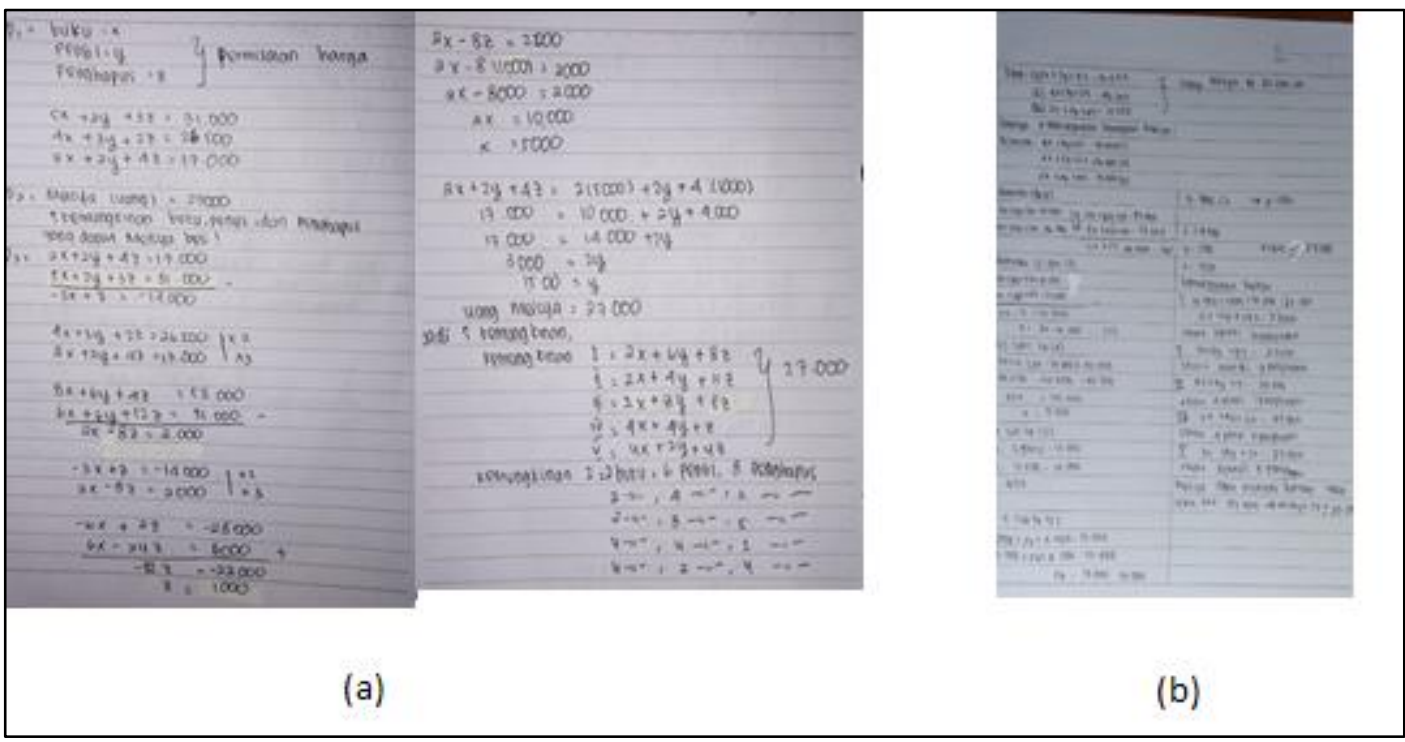

Figure 6. (a) The third answer of LS, (b) the third answer of ARAD

UA can write only one possible answer, but he has not written the calculation. However, FMR can find the price per item, but FMR has not written down any possibilities. Meanwhile, FAS can write 
Jurnal Prima Edukasia, 9 (1), 2021 - 132

Nursiwi Nugraheni, St. Budi Waluya, Walid Walid

down five possible answers even though the calculations are incorrect. Thus, the three students are considered to have difficulties in interpreting mathematical problems, which affect solving mathematical problems. LS, ARAD, and MD can write down five possible answers correctly. Based on previous explanations, students with moderate Self-Regulated Learning have difficulties in interpreting the questions and are not familiar with re-examining steps of problem-solving and causing them to be categorized in this category, such as FAS, who made a calculation error that causes the answer to be less than perfect. It causes a significant difference between students with high and moderate Self-Regulated Learning.

Self-Regulated learning is an effort applied for conducting learning activities independently based on their motivation to master a certain material, and it can be applied to solve problems (Egok, 2016). Each individual takes the initiative without the others' help, such as finding learning activities that are by the learning objectives, learning resources, and learning needs and controlling the learning process by themselves (Bungsu et al., 2019). Adult students can be considered as independent, such as in the learning process. Hence, the students must be able to make every decision for their future since learning attempts to reach their dream and future. Students will show better academic achievement, motivation, and learning when they have high Self-Regulated Learning (Sundayana, 2018). Therefore, to affect students' learning success, Self-Regulated Learning also affects students' mathematical reasoning abilities (Fajriyah et al., 2019). According to previous studies, Self-Regulated Learning affects learning achievement and Mathematical critical thinking skills. Therefore, following the essentials of mathematics in our daily and future life, mathematics learning should develop the students to be proficient in mathematics as they need to overcome the challenge in the future (Arifin et al., 2020). Daily problems as the topic of learning will make the students more enthusiastic in understanding the Learning (Sari, 2018). Students who have strong goals tend to do something systematically to prepare for their future. According to Muhandaz et al. (2018)), Self-Regulated Learning indicators consist of nine indicators, including (1) Initiative and learning motivation; (2) Learning needs that are diagnosed ; (3) The objectives in learning; (4) The organization, monitor, and the control of the learning process; (5) Difficulties that are viewed as challenges; (6) Relevant sources to be utilized and identified; (7) Learning strategies that are chosen and implemented and; (8) The process of learning outcomes that is evaluated and, (9) Selfefficacy/self-concept/self-ability. Planning, responsibility, initiative, self-confidence, discipline, and self-evaluation are some aspects of student learning independence (Arista \& Kuswanto, 2018). Based on these indicators, students with a high level of Self-Regulated Learning meet all the criteria of SRL. Self-Regulated learning is not formed immediately, but it takes is a long process. The students must practice for weeks, months, and years to improve their Self-Regulated Learning. Students who have high SRL always try to complete any exercises or assignments given by the teacher with their abilities, such as solving Mathematical problems (Sole \& Anggraeni, 2020). In understanding and analyzing problems from lecturers, independence is needed (Ediansyah et al., 2019). Hence, their ability to interpret questions will be very good. SRL is also used to evaluate the learning process and learning outcomes. When students want to identify differences between current and desired performance by assessing their work aimed at improving performance, self-assessment occurs (Ratminingsih et al., 2018). As a result, the accuracy in solving mathematical problems is high, and SRL is one of the determining factors of students' HOTS. The need for the development of a thorough attitude towards the process of mastering the main knowledge, expertise, skills and experience in a professional environment has been emphasized in the results of the experiment defining the maturity level of self-organizing skills(Alexandrovna, 2018).

\section{Conclusion}

Based on the research results, the conclusions are: (1) students with moderate Self-Regulated Learning category interpret the questions into Mathematical language, but the way they identify the problem is less communicative, while the students with high Self-Regulated Learning category interpret the questions into Mathematical language communicatively. However, none of the respondents has been able to see the concept of perimeter and distance between trees, which is slightly different due to the intersect point; (2) Based on the ability to evaluate, students with moderate SRL category are still not perfect, while students with high SRL category have been already fluent in evaluating; and (3) Based on their creative abilities, the students with moderate SRL category still need more practices, while the 
Jurnal Prima Edukasia, 9 (1), 2021 - 133

Nursiwi Nugraheni, St. Budi Waluya, Walid Walid

students with high SRL category have been fluent. The significant differences between the two categories are the ability to interpret problems and the habit of re-checking Mathematical problemsolving. This data can be used by researchers as a reference to improve students' high order thinking skills.

\section{References}

Agung Ramadan, Y., Masrukan, M., \& Mulyono, M. (2020). Upaya peningkatan high order thinking skills melalui accelerated learning pendekatan inferentilialism. JARTIKA : Jurnal Riset Teknologi Dan Inovasi Pendidikan, 3(1), 84-96. https://doi.org/10.36765/jartika.v3i1.35

Alexandrovna, R. N. (2018). Development of independence among future primary school teachers by applying interactive learning methods. Journal of Education and E-Learning Research, 5(2), 118-121. https://doi.org/10.20448/journal.509.2018.52.118.121

Arifin, S., Wahyudin, W., \& Herman, T. (2020). The effects of contextual group guided discovery learning on students' mathematical understanding and reasoning. Jurnal Prima Edukasia, 8(2), 106-114. https://doi.org/10.21831/jpe.v8i2.33059

Arista, F. S., \& Kuswanto, H. (2018). Virtual physics laboratory application based on the android smartphone to improve learning independence and conceptual understanding. International Journal of Instruction, 11(1), 1-16. https://doi.org/10.12973/iji.2018.1111a

Bungsu, T. K., Vilardi, M., Akbar, P., \& Bernard, M. (2019). Pengaruh kemandirian belajar terhadap hasil belajar matematika di SMKN 1 Cihampelas. Journal on Education, 1(2), 382-389. https://jonedu.org/index.php/joe/article/view/78

Citrasukmawati, A., Julianingsih, D., \& Trisnawaty, W. (2020). Development of science chess media based on Higher Order Thinking Skill (HOTS) to increase the understanding of science concept in students. Journal of Physics: Conference Series, 1440(1). https://doi.org/10.1088/1742$6596 / 1440 / 1 / 012101$

Ediansyah, E., Kurniawan, D. A., Salamah, S., \& Perdana, R. (2019). Investigation of problem based learning: process of understanding the concepts and independence learning on research statistics subject. Humanities \& Social Sciences Reviews (HSSR), 7(5), 1-11. https://doi.org/https://doi.org/10.18510/hssr.2019.751

Edwar, E. (2020). Professional development of teachers and development of teaching material in higher order thinking skill (HOTS) with mathematical realistic approach. Companion Proceedings of the 7th South East Asia Design Research International Conference (SEADRIC 2019), 2019(July 2019), 1-5. https://doi.org/10.24071/seadr.2019.01

Egok, A. S. (2016). Kemampuan berpikir kritis dan kemandirian belajar dengan hasil belajar matematika. Jurnal Pendidikan Dasar, 7(2), 186. https://doi.org/10.21009/JPD.072.01

Fajriyah, L., Nugraha, Y., Akbar, P., \& Bernard, M. (2019). Pengaruh kemandirian belajar siswa SMP terhadap kemampuan penalaran matematis. Journal on Education, 1(2), 288-296. https://jonedu.org/index.php/joe/article/view/66

Fanani, M. Z. (2018). Strategi pengembangan soal HOTS pada Kurikulum 2013. EDUDEENA, 2(1), 57-76. https://doi.org/10.30762/ed.v2i1.582

Ichsan, I. Z., Sigit, D. V., Miarsyah, M., Ali, A., \& Suwandi, T. (2020). Implementation supplementary book of green consumerism: Improving students HOTS in environmental learning. European Journal of Educational Research, 9(1), 227-237. https://doi.org/10.12973/eu-jer.9.1.227

Kusuma, M. D., Rosidin, U., Abdurrahman, A., \& Suyatna, A. (2017). The development of higher order thinking skill (Hots) instrument assessment in physics study. IOSR Journal of Research \& Method in Education (IOSRJRME), 07(01), 26-32. https://doi.org/10.9790/7388-0701052632

Muhandaz, R., Trisnawita, O., \& Risnawati, R. (2018). Pengaruh model pembelajaran course review horay terhadap kemampuan pemahaman konsep matematis berdasarkan kemandirian belajar siswa SMK Pekanbaru. JURING (Journal for Research in Mathematics Learning), 1(2), 137. https://doi.org/10.24014/juring.v1i2.6552 
Jurnal Prima Edukasia, 9 (1), 2021 - 134

Nursiwi Nugraheni, St. Budi Waluya, Walid Walid

Payadnya, I. P. A. A., \& Atmaja, I. M. D. (2020). Application of "what-if" learning strategy to improve students' mathematical critical thinking skills in statistical method I subject. Journal of Physics: Conference Series, 1470, 012044. https://doi.org/10.1088/1742-6596/1470/1/012044

Pratama, G. S., \& Retnawati, H. (2018). Urgency of Higher Order Thinking Skills (HOTS) content analysis in mathematics textbook. Journal of Physics: Conference Series, 1097(2018), 012147. https://doi.org/10.1088/1742-6596/1097/1/012147

Ratminingsih, N. M., Marhaeni, A. A. I. N., \& Vigayanti, L. P. D. (2018). Self-assessment: The effect on students' independence and writing competence. International Journal of Instruction, 11(3), 277-290. https://doi.org/10.12973/iji.2018.11320a

Sari, I. K. (2018). The effect of problem-based learning and project-based learning on the achievement motivation. Jurnal Prima Edukasia, 6(2), 129-135. https://doi.org/10.21831/jpe.v6i2.17956

Setiawati, W., Asmira, O., Ariyana, Y., Bestary, R., \& Pudjiastuti, A. (2018). Buku penilaian berorientasi higher order thinking skills. Direktorat Jenderal Guru dan Tenaga KependidikanKementerian Pendidikan dan Kebudayaan.

Shidiq, A. S., Masykuri, M., \& Susanti, E. (2015). Analisis Higher Order Thinking Skills (HOTS) menggunakan instrumen two-tier multiple choice pada materi kelarutan dan hasil kali kelarutan untuk siswa kelas XI SMA N 1 Surakarta. Prosiding Seminar Nasional Pendidikan Sains, November, 2015-2159.

Sole, F. B., \& Anggraeni, D. M. (2020). Analysis of High Order Thinking Skill (HOTS) in joint midterm examination at YAPNUSDA Elementary School. Journal of Physics: Conference Series, 1440(1), 012102. https://doi.org/10.1088/1742-6596/1440/1/012102

Sundayana, R. (2018). Kaitan antara gaya belajar, kemandirian belajar, dan kemampuan pemecahan masalah siswa SMP dalam pelajaran matematika. Mosharafa: Jurnal Pendidikan Matematika, 5(2), 75-84. https://doi.org/10.31980/mosharafa.v5i2.262

Widana, I. W. (2017). Higher order thinking skills assessment (HOTS). Jisae: Journal of Indonesian Student Assesment and Evaluation, 3(1), 32-44. https://doi.org/10.21009/JISAE.031.04 